\title{
Optimalisasi Usaha Kelompok Pemuda Pengrajin Anyaman Paku Atta Dalam Upaya Pemasaran Produk Secara Online
}

\author{
Ni Made Estiyanti, Sephy Lavianto \\ Sekolah Tinggi Manajemen Informatika dan Komputer (STMIK) \\ Primakara
}

\begin{abstract}
ABSTRAK
Industri Anyaman Atta menempati posisi yang paling tinggi dalam data potensi perindustrian dan perdagangan Kabupaten Karangasem tahun 2017. Industri Anyaman Atta mempunyai unit usaha sebanyak 3.569 dengan jumlah penyerapan tenaga kerja sebanyak 5.838 orang. Namun pemasaran secara langsung untuk menembus pasar nasional dan internasional masih belum tercapai karena para pengrajin belum bias memanfaatkan memanfaatkan pemasaran secara online sesuai dengan perkembangan zaman sekarang. Mitra dalam program Iptek bagi Masyarakat ini adalah Kelompok Pemuda Pengrajin Anyaman Atta Eka Genta. Kelompok Pengrajin ini berkedudukan di Banjar Desa, Desa Bungaya, Kecamatan Bebandem, Kabupaten Karangasem. Tujuan pelaksanaan pengabdian masyarakat ini adalah untuk memberikan pelatihan dan pemahaman marketing online produk anyaman paku atta melalui media social seperti facebook dan Instagram. Metode pengabdian yang digunakan adalah metode ceramah, workshop, praktik. Hasil dari pengabdian masyarakat ini berupa media sosial online berupa facebook, Instagram dari para anggota pemuda pengrajin anyaman paku atta dan adanya peningkatan omzet penjualan dan pelanggan dari masing-masing pengrajin.
\end{abstract}

Kata Kunci : Marketing Online, Media Sosial, Omzet Penjualan

\section{PENDAHULUAN}

\section{Analisis Situasi}

Kabupaten Karangasem yang terletak di ujung Timur Pulau Bali dan merupakan salah satu dari 9 Kabupaten/ Kota yang ada di Propinsi Bali. Berdasarkan Data Potensi Industri dan Perdagangan Kabupaten Karangasem, terlihat bahwa kondisi perdagangan, industri kecil dan menengah (IKM) di Kabupaten Karangasem terbagi dalam kategori Kelompok Formal dan Kelompok Non Formal. Dari kedua kategori tersebut secara umum Kelompok Non Formal mempunyai peran lebih besar dari segi jumlah unit usaha maupun penyerapan tenaga kerja bila dibandingkan dengan Kelompok Formal. Berikut ini data Perdagangan, Industri Kecil dan Menengah Kabupaten Karangasem sampai dengan Tahun 2017 yang diklasifikasikan berdasarkan kecamatan. 
Tabel 1 .Data Potensi Perdagangan Kabupaten Karangasem

\begin{tabular}{|c|c|c|c|c|c|}
\hline NO & $\underset{\mathbf{N}}{\operatorname{KECAMAT} t}$ & $\begin{array}{l}\text { PERDAGANG } \\
\text { AN FORMAL }\end{array}$ & $\begin{array}{l}\text { PERDAGANG } \\
\text { AN GLOBAL }\end{array}$ & $\begin{array}{l}\text { INDUSTRI } \\
\text { FORMAL }\end{array}$ & $\begin{array}{c}\text { INDUSTRI } \\
\text { NON }\end{array}$ \\
\hline 1 & Abang & 79 & 2.137 & 32 & 1.376 \\
\hline 2 & Bebandem & 71 & 3.101 & 83 & 1.153 \\
\hline 3 & Karangasem & 388 & 5.037 & 164 & 2.318 \\
\hline 4 & Kubu & 76 & 1.269 & 22 & 2.436 \\
\hline 5 & Manggis & 70 & 2.002 & 28 & 1.652 \\
\hline 6 & Rendang & 54 & 2.667 & 44 & 541 \\
\hline 7 & Selat & 47 & 607 & 56 & 1.842 \\
\hline 8 & Sidemen & 20 & 730 & 30 & 2.596 \\
\hline & TOTAL & 805 & 17.550 & 459 & 13.914 \\
\hline
\end{tabular}

Sektor Perdagangan serta Industri Kecil dan Menengah di Kabupaten Karangasem memberikan peranan besar dalam peningkatan pertumbuhan ekonomi kerakyatan karena Industri dan Perdagangan ini mandiri dalam memenuhi kebutuhan pasar lokal maupun regional, industri dan perdagangan yang mampu menyerap banyak tenaga kerja, serta industri dan perdagangan yang mampu bertahan dalam situasi krisis Global. Maka keberadaan perdagangan serta Industri Kecil dan Menengah di Kabupaten Karangasem layak mendapatkan perhatian yang lebih dalam pengembangan dan pembinaan secara menyeluruh dan berkelanjutan untuk bisa bersaing dalam persaingan pasar modern.

Data potensi perindustrian dan perdagangan Kabupaten Karangasem tahun 2014 juga menyajikan data tentang industri kecil menengah non formal menurut cabang industri. Berdasarkan data tersebut, industri anyaman Atta menempati posisi yang paling tinggi dalam kategori jumlah unit usaha, penyerapan tenaga kerja, dan nilai produksi. Industri Anyaman Atta mempunyai unit usaha sebanyak 3.569 dengan jumlah penyerapan tenaga kerja sebanyak 5.838 orang. Nilai investasinya sebesar Rp 1.773.571.000,00 dan nilai produksinya sebesar Rp 12.520.775.000,00. Industri Anyaman Atta ini tersebar di hampir seluruh kecamatan di Kabupaten Karangasem. 
Gambar 1. Hasil Kerajinan Anyaman Paku Atta
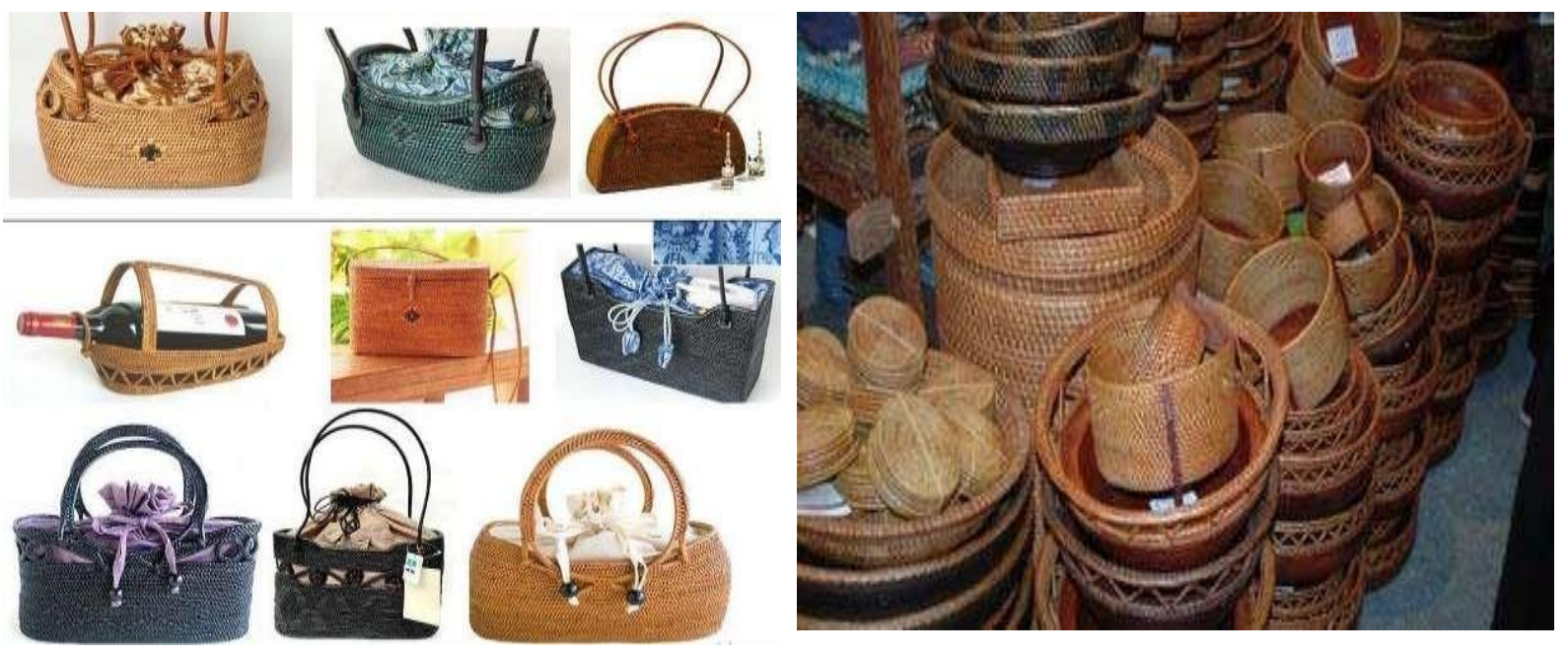

Sumber: Data Potensi Industri dan Perdagangan Kab. Karangasem. http://www.karangasemkab.go.id

Gambar 1 di atas adalah beberapa contoh produk hasil kerajinan Anyaman Atta. Anyaman Atta ini memiliki banyak bentuk dan desain. Mulai dari jenis tas, alas piring, alas gelas, gerabah, tutup gelas, tempat tissue, tempat buah, dan sebagainya. Selain itu produk bisa dengan mudah dimodifikasi dengan bahan lain seperti tempurung, kain, kayu, pandan dan kulit.

Sejalan dengan perkembangan teknologi dan informasi, para pengrajin paku atta sangat tertinggal dalam masalah pemasaran produknya dimana hal ini disebabkan karena ketidakmampuan mereka dalam menggunakan teknologi informasi terutama media sosial untuk melakukan pemasaran online untuk menembus pasar nasional dan internasional. Pengrajin atta yang rata-rata berasal dari desa dan jarang memanfaatkan pemasaran melalui online membuat omzet penjualan mereka cukup sulit didapatkan di tengah-tengah serbuan produk-produk kerajinan yang lain yang sudah terlebih dahulu dipasarkan secara online melalui media sosial marketing. Melalui pengabdian masyarakat ini, kami bermaksud untuk memberikan pelatihan dan pendampingan kepada kelompok pemuda pengrajin atta untuk bisa menggunakan media sosial dalam melakukan pemasaran produk mereka selama 1 tahun.

\section{Permasalahan Mitra}

Kemampuan yang rendah dalam menggunakan dan memanfaatkan media sosial untuk penjualan produk secara online dalam persaingan perdagangan sesuai dengan tuntutan zaman sekarang. Dalam pengabdian masyarakat ini, para anggota pemuda pengrajin anyaman atta yang ditargetkan sebagai kelompok binaan sebanyak 75 orang yang terhimpun pada Kelompok Pemuda Pengrajin Atta Eka Genta. 


\section{Solusi}

Solusi yang ditawarkan dalam pengabdian ini adalah memberikan pelatihan, workshop dan pendampingan tentang pemanfaatan media sosial facebook dan Instagram dalam upaya pemasaran online produk kerajinan atta. Untuk memperoleh hasil yang optimal, perencanaan proses pelatihan, workshop dan pendampingan perlu dilakukan beberapa tahapan yaitu; (1)perencanaan dan (2)pelaksanaan.

\section{Target Luaran}

Adapun yang ditargetkan menjadi luaran dari kegiatan ini adalah para peserta mampu membuat dan mengelola akun media sosial facebook atau Instagram untuk memasarkan produk mereka.

\section{METODE PELAKSANAAN}

\section{Metode Penerapan Kegiatan}

a. Ceramah

Metode ini dimaksudkan untuk memberikan materi pengetahuan tentang teori membuat dan mengelola akun facebook atau Instagram untuk pemasaran online. Disamping itu diberikan pula materi tentang fotografi produk.

b. Pelatihan dan Workshop

Pada bagian ini para peserta yang terdiri dari 75 orang kelompok pemuda pengrajin atta diajak untuk mempraktekkan membuat akun facebook atau Instagram pada telepon pintar mereka masing-masing. Membuat nama online shop mereka dan bagaimana membuat dan menggunakan hashtag yang cocok untuk pemasaran produk mereka. Setelah itu mereka diajak untuk mengupload foto produk yang sudah dipersiapkan sebelumnya.

\section{c. Pendampingan}

Pendampingan dilakukan selama 6 (enam) bulan untuk mendampingi pengelolaan akun tersebut dan melihat perkembangan akun media online shop mereka.

\section{Peserta Pengabdian}

Peserta yang ikut dalam kegiatan pengabdian pada masyarakat ini adalah para para pemuda pengrajin anyaman paku atta yang tergabung dalam kelompok pemuda pengrajin atta Eka Genta. Adapun jumlah peserta yang mendaftar dalam pelatihan adalah sebanyak 75 orang.

\section{Waktu dan Tempat pengabdian}

Kegiatan pengabdian pada masyarakat ini dilaksanakan pada bulan September 2018 sampai dengan Mei 2019 yang dilaksanakan di Desa Bungaya, Kecamatan Bebandem, Kabupaten Karangasem. 


\section{HASIL DAN PEMBAHASAN}

\section{Kegiatan Pendahuluan}

Dalam tahap ini dilakukan kegiatan berikut:

1) Tahap Perencanaan

Pada tahap perencanaan ini dilakukan beberapa proses kegiatan. Adapun hal-hal yang dilakukan adalah melakukan pengumpulan data tentang potensi UMKM di Kabupaten Karangasem, berkonsultasi dengan UKM Center Kabupaten Karangasem untuk mencari data tempat centra-centra kerajinan atta. Hal lain yang dipersiapkan seperti materi untuk pelatihan dan jadwal, pembicara, teknis pelatihan dan pendampingan. Dengan harapan semua kegiatan berjalan dengan lancar.

2) Tahap Pendekatan

Adapun hal-hal yang dilakukan adalah melakukan survey dan pendekatan kepada Kelompok pemuda pengrajin atta Eka Genta Desa Bungaya untuk mendapatkan beberapa data seperti data anggota, sosialisasi kegiatan pelatihan dan penentuan waktu kegiatan. Beberapa kesepakatan tentang sarana yang mendukung pelatihan yang harus dipersiapkan oleh peserta , sehingga kegiatan berjalan maksimal.

\section{Kegiatan Pelaksanaan}

Tahapan pelaksanaan program diawali dengan kegiatan pelatihan dan workshop penggunaan media sosial marketing yang dilaksanakan pada bulan September 2018. Pelatihan diawali dengan pemberian teori dan materi tentang pembuatan akun media sosial facebook dan Instagram, cara memanfaatkan untuk keperluan pemasaran produk, cara upload foto produk, sekilas tentang fotografi foto produk dan bagaimana mengelola akun tersebut. Setelah itu peserta langsung mempraktekkan dengan pembuatan akun media sosial dan mengupload beberapa foto produk secara mandiri.

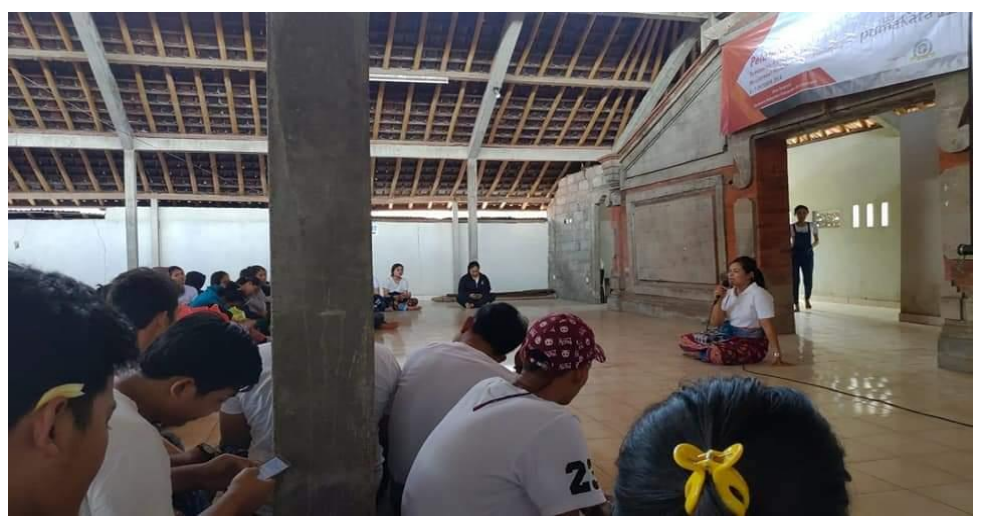

Gambar 2. Penjelasan tentang sosial media marketing 


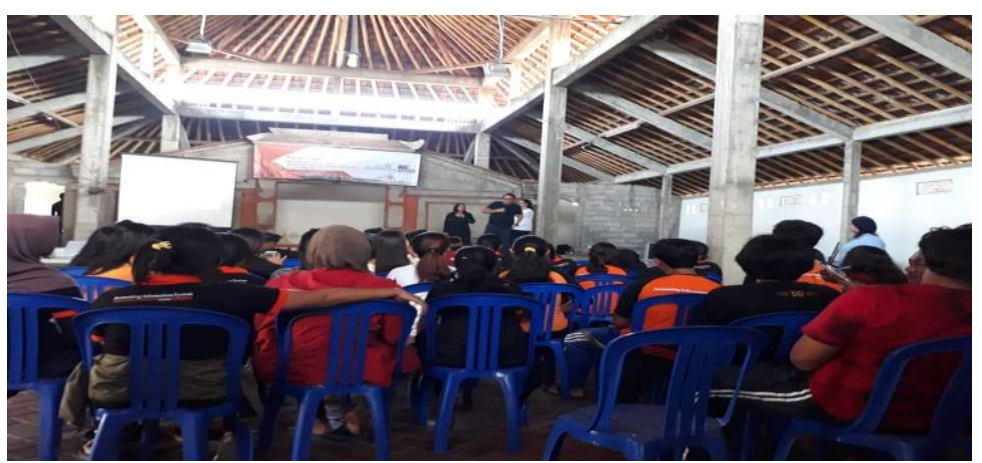

Gambar 3. Workshop sosial media marketing

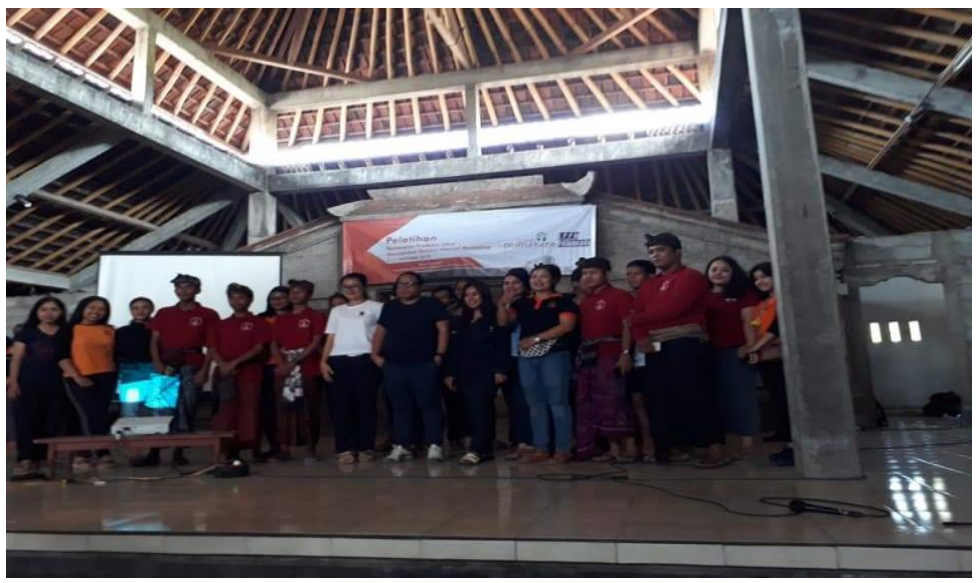

Gambar 4. Foto bersama dengan kelompok pemuda pengrajin atta Eka Genta

\section{Hasil Kegiatan}

Pelatihan ini memberikan manfaat bagi kelompok pemuda pengrajin atta Eka Genta dalam penggunaan media sosial khususnya facebook dan Instagram dalam upaya pemasaran produk kerajinan paku atta secara nasional dan global. Para peserta pelatihan antusias mengikuti kegiatan selama workshop dan pelatihan. Gambar 5 dan gambar 6 di bawah ini adalah akun media sosial dari peserta pelatihan. 


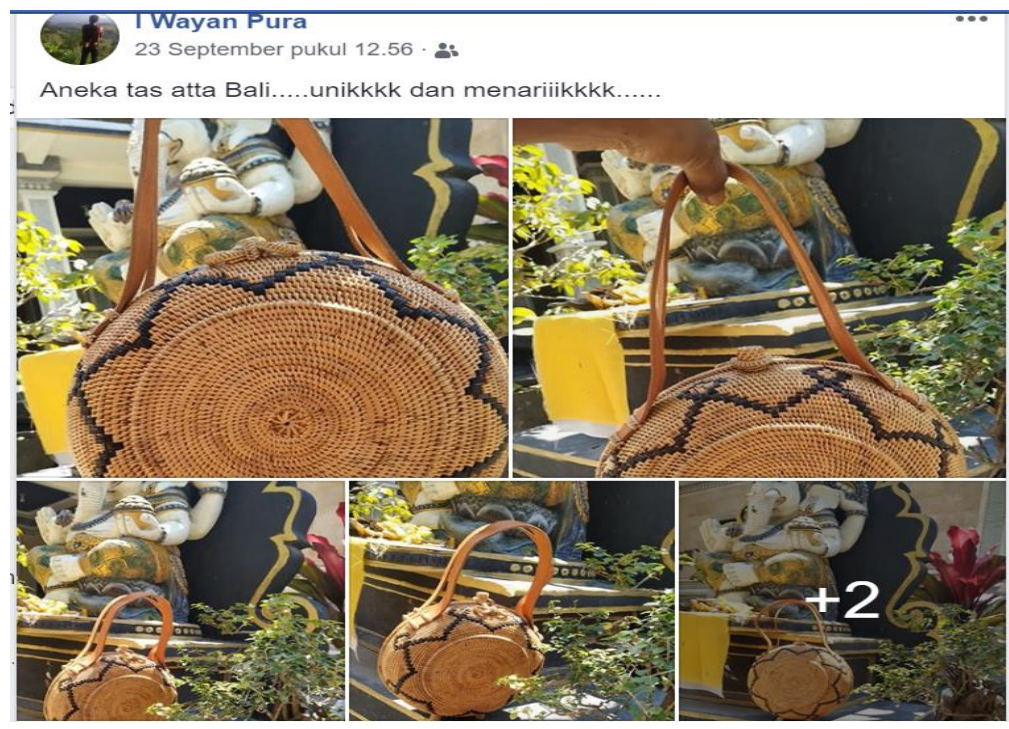

Gambar 5. Salah satu akun facebook dari peserta kegiatan

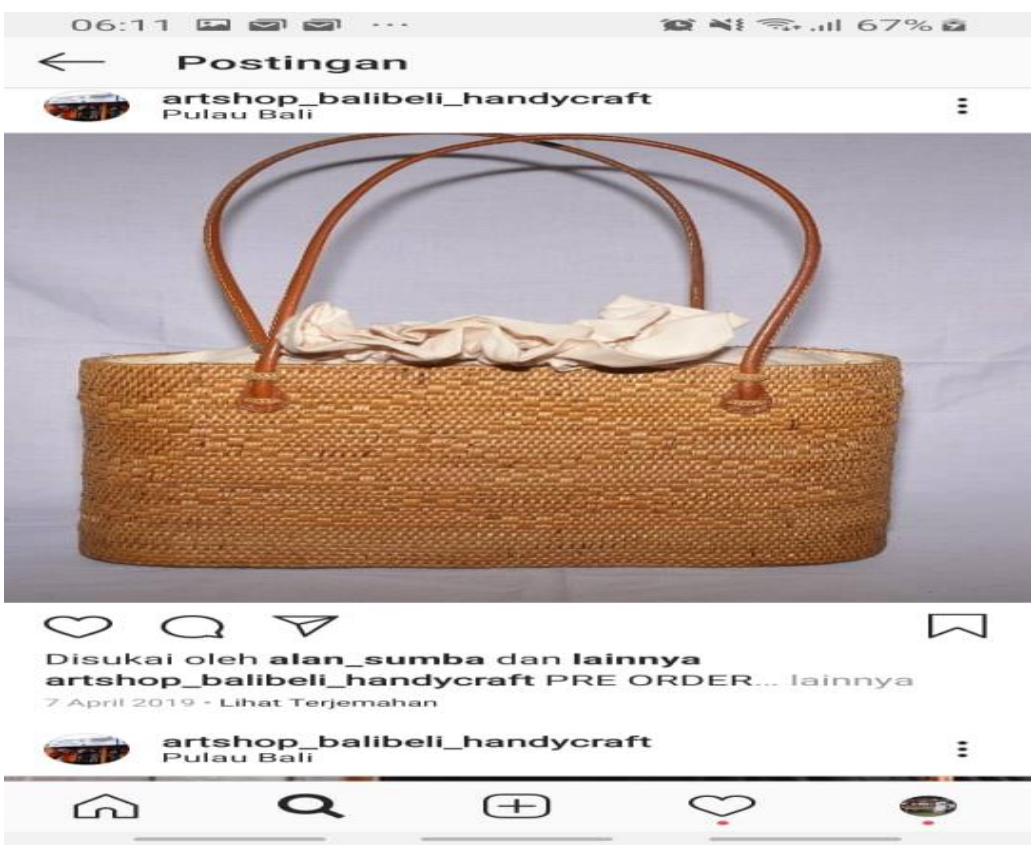

Gambar 5. Salah satu unggahan akun instagram dari peserta kegiatan

Para peserta pelatihan selama masa pendampingan dari bulan September 2018 sampai dengan Bulan april 2019, secara aktif melakukan pengelolaan terhadap akun media sosial mereka. Beberapa pengrajin mendapatkan order dari pelanggan nasional dan dari luar negeri. 
Produk kerajinan tas atta yang sedang trendi saat itu membuat akun media sosila pengrajin atta banyak yang memberikan like, komentar dan terjadi peningkatan penjualan.

\section{KESIMPULAN DAN SARAN}

Pelaksanaan kegiatan pelatihan dan pendampingan pemanfaatan media sosial untuk pemasaran produk kerajinan atta dengan mitra kelompok pemuda pengrajin atta Eka Genta sudah terlaksana dengan baik. Para peserta mampu memahami pentingnya pemasaran secara digital melalui akun media sosial pada jaman sekarang ini . Peserta mampu mengelola akun media sosial mereka untuk melakukan promosi dan penjualanproduk kerajinan paku atta yang mereka hasilkan. Tanggapan peserta terhadap pelaksanaan kegiatan pelatihan dan workshop ini sangat baik, dimana hal ini dapat dilihat dari respon yang diberikan oleh peserta selama kegiatan berlangsung, baik yang dapat dilihat dari proses diskusi, bertanya, maupun menjawab. Selama kegiatan pendampingan selama 6 (enam) bulan, peserta secara aktif melakukan diskusi, konsultasi dan bertanya berkenaan dengan pengelolaan dan penanganan konsumen sebagai hasil dari penggunaan media sosial faceebook dan Instagram mereka.

Penulis berharap kegiatan pelatihan dan pendampingan bagi kelompok pemuda pengrajin atta ini bisa dilaksanakan secara terus-menerus. Adapun kegiatan lanjutan yang bisa dilaksanakan sebagai lanjutan kegiatan ini adalah memberikan pelatihan bahasa inggris, pelatihan yang berkenaan dengan cara pengiriman barang di dalam negeri dan luar negeri (logistic dan shipping).

\section{DAFTAR PUSTAKA}

Banerjee Sonali \& Sunetra Saha. 2012. Impulse Buying Behavior in Retail Store Triggering the Sense. Asia Pasific Journal of Marketing and Management Review, Vol. 1 No. 2, ISSN 2319-2836.

Badan Pusat Statistik Kabupaten Karangasem. Data Potensi Industri dan Perdagangan Kabupaten Karangasem. https://karangasemkab.bps.go.id/

Elitemarketer. (2018) ; https://digitalmarketer.id/socialmedia/ fitur-bisnis-instagram akansegera-muncul-untuk-bisnis-anda

Soewandhi, Nurono Sundani, 2010. Sebuah Pemikiran Tentang Diseminasi Karya Pengabdian Kepada Masyarakat Perguruan Tinggi Indonesia. Majalah Aplikasi Iptekes Ngayah, $1(1), 2010,2-12$. 